\section{Fungusit tebukonazolün tatlı su midyelerine (Unio mancus) toksik etkilerinin çoklu biyobelirteçlerle incelenmesi}

\section{Investigation of toxic effects of fungicide tebuconazole on freshwater mussels (Unio mancus) with multiple biomarkers}

\section{ÖZET}

Triazol fungusitler, geniş spektrumlu, steroidal olmayan antiöstrojenler ve çeşitli endüstriyel uygulamalar için yaygın olarak kullanılmaktadır. Toprak, su gibi çevresel ortamlarda ve canlı organizmaların dokularında bu fungusitlerin kalıntılarına rastlanmaktadır. Giderek artan toksisite raporları, triazol fungusitlerin çevre ve halk sağlığı açısından endişe verici kirleticiler olarak ortaya çıkmasına neden olmuştur. Bu çalışmada, triazol grubu fungusitlerden en yaygın kullanılan türlerinden biri olan tebukonazolün (TEB) hedef dışı organizmalar olan tatlı su midyeleri (Unio mancus) üzerindeki toksik etkileri incelenmiştir. Çalışmada, 96 saat boyunca dört TEB konsantrasyonuna $\left(1.5,15,150\right.$ ve $\left.1500 \mu \mathrm{g} \mathrm{AI} \mathrm{L}^{-1}\right)$ maruz birakılan midyelerin solungaç ve sindirim bezlerinde çeşitli oksidatif stres parametreleri [toplam antioksidan konsantrasyonu (TAC), toplam oksidan konsantrasyonu (TOC), oksidatif stres indeksi (OSI), glutatyon (GSH), malondialdehit (MDA)], antioksidan enzimler [(süperoksit dismutaz (SOD), glutatyon peroksidaz (GPx), glutatyon S-transferaz (GST), glutatyon redüktaz (GR)] ve biyotransformasyon enzimlerinden karboksil esteraz $(\mathrm{CaE})$ aktivitesi değerlendirilmiştir. TEB'e maruz kalmanın hem solungaçta hem de sindirim bezinde kontrole göre önemli oranda TAC, OSI, MDA seviyelerini arttırdığı, TOC ve GSH düzeylerini düşürdüğü, SOD, GPx, GST aktivitelerini arttırdığı, GR ve CaE'yi ise inhibe ettiği gözlenmiştir. Sonuç olarak, TEB'in $U$. mancus'da önemli toksik etkiler oluşturduğu ve tatlı su ekosistemlerinde yaşayan midyelerin TEB'e maruz kalma tehdidi altında olabileceği söylenebilir.

Anahtar Kelimeler: Biyobelirteçler, oksidatif stres, tatlısu midyeleri, tebukonazol

\section{ABSTRACT}

Triazole fungicides are widely used as broad-spectrum, non-steroidal antiestrogens and for various industrial applications. Residues of these fungicides are found in environments such as soil and water, and in the tissues of living organisms. Increasing toxicity reports have led to the emergence of triazole fungicides as pollutants of environmental and public health concern. In this study, the toxic effects of tebuconazole (TEB), one of the most widely used triazole fungicides, on freshwater mussels (Unio mancus), which are non-target organisms, were investigated. In the study, various oxidative stress parameters [total antioxidant concentration (TAC), total oxidant concentration (TOC), oxidative stress index (OSI), glutathione (GSH), malondialdehyde (MDA)], antioxidant enzymes [(superoxide dismutase (SOD), glutathione peroxidase (GPx), glutathione S-transferase (GST), glutathione reductase (GR)] and carboxylesterase $(\mathrm{CaE})$ activity from biotransformation enzymes was evaluated in the gill and digestive glands of mussels exposed to four TEB concentrations $(1.5,15,150$

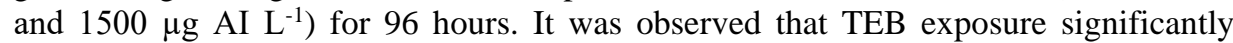
increased TAC, OSI, MDA levels, decreased TOC and GSH levels, increased SOD, GPx, GST activities, and inhibited GR and $\mathrm{CaE}$ activities in both the gill and digestive gland compared to the control. As a result, it can be said that TEB has significant toxic effects on $U$. mancus and mussels living in freshwater ecosystems may be under the threat of TEB exposure.

Keywords: Biomarkers, oxidative stress, freshwater mussels, tebuconazole

\section{How to cite this article}

Uçkun M. (2021). Investigation of toxic effects of fungicide tebuconazole on freshwater mussels (Unio mancus) with multiple biomarkers. Journal of Advances in VetBio Science and Techniques, 6(3), 284-297. https://doi.org/10.31797/vetbio.1014522
Research Article

Miraç Uçkun

Department of Food Engineering, Faculty of Engineering, Adiyaman University, Adiyaman, Turkey

ORCID-

$\underline{0000-0002-9018-8515}$

Correspondence

Miraç UÇKUN

m.uckun@adiyaman.edu.tr

Article info

Submission: 25-10-2021

Accepted: 29-12-2021

e-ISSN: 2548-1150

doi prefix: $10.31797 /$ vetbio

- http://dergipark.org.tr/vetbio

This work is licensed under a Creative Commons Attribution 4.0 International License (c) (i) 


\section{İRIȘ}

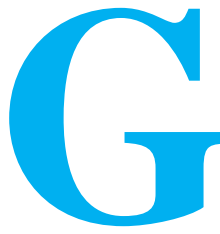

Azoller, geniş spektrumlu antifungal aktivitesi ve yüksek stabilitesi nedeniyle mantar enfeksiyonlarına karşı bitki koruması, insan mikozunun tedavisi ve veterinerlik tıbbı için yaygın olarak kullanılan antimikotik ajanlardır (Bhagat vd., 2021). İlaçların yanı sıra azol bileşikleri uçaklarda aşındırıcı inhibitörler (McNeill ve Cancilla, 2009), çamaşır tozu (Janna vd., 2011) ve şampuan, krem, köpük, diş macunu gibi kişisel bakım ürünlerinde de kullanılmaktadır (Allen vd., 2015). Azoller, dünya çapında yıllık 300,000 ton civarında olan fungisit kullanımının büyük bir kısmını oluşturmaktadır (De vd., 2014). Çevrede yaygın olarak bulunması nedeniyle, suda yaşayan organizmalar üzerindeki zararlı etkileri konusunda endişeler vardır (Nong vd., 2021). Azol bileşikleri güçlü bakterisidal aktiviteye sahiptir ve biyolojik bozunmaya karş1 dirençlidir. Azol, hücre zarı bütünlüğü için gerekli olan lanosterolü ergosterole dönüştüren bir sitokrom P450 (CYP) enzimi olan lanosterol 14-alpha-demetilaz1 (CYP51A1) inhibe eder. Dolayısıyla hücre zarının kaybı ve inhibisyonu, azolün antifungal doğasının arkasındaki ana mekanizmalardan biridir (García-Valcárcel ve Tadeo, 2012).

Tablo 1. Ticari pestisit formülasyonu ve etken maddenin fiziko-kimyasal özellikleri, ${ }^{a}$

\begin{tabular}{|c|c|}
\hline & Pestisit \\
\hline & Orius $25 \mathrm{EW}$ \\
\hline Ticari konsantrasyon & $250 \mathrm{~g} \mathrm{AI} \mathrm{L}^{-1}$ \\
\hline \multirow{2}{*}{ Etken madde } & Tebukonazol \\
\hline & Etken maddenin fiziko-kimyasal özellikleri \\
\hline \multicolumn{2}{|l|}{ Yapısal formüller } \\
\hline Etken madde grubu & Triazol \\
\hline Pestisit tipi & Fungisit \\
\hline Toksikolojik sınıf & III \\
\hline Moleküler ağırlık (g/mol) & 307.8 \\
\hline Lipofilisite $\left(\log K_{o w}\right)$ & $3.7\left(20^{\circ} \mathrm{C}\right.$ ve $\left.\mathrm{pH} 7.0\right)$ \\
\hline Toprak afinitesi $\left(\log K_{o c}\right)$ & $2.96-3.10$ \\
\hline Sudaki çözünürlük (mg/L) & $32\left(20^{\circ} \mathrm{C}\right)$ \\
\hline GUS potansiyel sızma indeksi & 1.86 \\
\hline Sudaki fotoliz yarılanma süresi $\left(\mathrm{DT}_{50}\right.$, gün) ${ }^{\text {b }}$ & Stabil \\
\hline Sudaki hidroliz yarılanma süresi (DT50, gün) & Stabil \\
\hline $\begin{array}{c}\text { Topraktaki kalıcılık süresi (DT } 50 \text {, gün, aerobik } \\
\text { koşullarda) }\end{array}$ & $\sim 800$ \\
\hline Yüzey sularındaki konsantrasyon aralığı $\left(\mu g \mathrm{~L}^{-1}\right)$ & $9.1 \mu \mathrm{g} \mathrm{L}^{-1} \sim 200 \mu \mathrm{g} \mathrm{L}^{-1}$ \\
\hline
\end{tabular}

${ }^{a}$ Kaynaklar: PPDB, 2021; EFSA, 2008; Nikolaou vd. 2017; IUPAC 2019; Jiang vd. 2021.

${ }^{b}$ Bileşikler anaerobik koşullar altında su ve toprakta çok daha kararlıdır.

${ }^{c}$ Bileşikler asidik veya nötr $\mathrm{pH}$ koşulları altında hidrolize karşı stabildir, ancak alkali koşullar altında hidroliz meydana gelebilir. ( $\mathrm{pH}$ 9).

GUS: Groundwater Ubiquity Score; yeraltı suyu yaygınlık puanı, potansiyel sızma indeksi

$\log K_{o w}$ : oktanol-su bölme katsayısının logaritması

$\log K_{o c}$ : Organik karbon bölme katsayısının logaritması

$\mathrm{DT}_{50}$ : Yarılanma süresi; dağılım süresi $50 \%$.

Aİ [aktif ingrediyent]: etken madde 
Bununla birlikte, tebukonazolün endokrin bozulmas1, üreme toksisitesi ve embriyonik toksisite gibi dikkate değer toksikolojik etkileri vardır (Ma vd., 2021) ve insanlar için potansiyel bir kanserojen risk oluşturmaktadır (Liu vd., 2016). Azol bileşiklerinin tarımda, eczacılıkta ve kişisel bakım ürünlerinde aşırı kullanımı, su, toprak ve su organizmalarında kontaminasyona neden olmuştur. Nehirlerde, atık sularda, göllerde ve haliçlerde azollerin biriktiği rapor edilmiş̧tir (Pacholak vd., 2022).

Evsel kanalizasyon ve hastane atık sularının da yüksek miktarda azol bileşikleri içerdiği bildirilmiştir. Atık su arıtma tesisleri bu kaynaklardan büyük miktarda su alır ve azollerin giderilmesinde yetersizdir. $\mathrm{Bu}$ atık su aritma tesislerinden çıkan atık suların doğal çevreye salınması, azol kirliliğinin başlıca kaynaklarından biridir (Peng vd., 2012). Tebukonazol (TEB), ((RS)-1-p klorofenil-4,4dimetil-3-(1H-1,2,4-triazol-1-ilmetil) pentan-3ol), triazol ailesinin en iyi bilinen ve satılan sistemik fungisitidir. TEB'un ticari formülasyonu ve fiziko-kimyasal özellikleri ile ilgili bilgiler Tablo 1'de verilmiştir. TEB, yüksek lipofilik özelliklerinden dolayı toprakta çok kararlıdır ve toprak özelliklerine ve konjugenin başlangıç konsantrasyonuna bağlı olarak yarı ömrü 49-610 gündür (Sehonova vd., 2017). Yüzey sularında ve çiftliklerin yakınındaki sucul ortamlarda ölçülen TEB

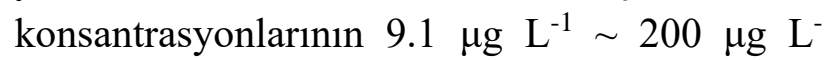
${ }^{1}$ aralığında olduğu tespit edilmiştir (Jiang vd., 2021). EPA (U.S.EPA, 2020) tarafindan belirlendiği üzere, TEB'in balıklar için suda yaşam limit değeri $1135 \mu \mathrm{g} \mathrm{L}^{-1}$, dir. Midyeler suda yaşayan bentik organizmalar olduğundan sudaki kirleticilerin etkilerini en iyi yansitan biyoindikatörlerden biridir (Naimo, 1995; Hongyi vd., 2009). U. mancus, IUCN Kirmızı Listesinde "Tehdit Altında" olarak listelenmiş olan bir tatlı su midye türüdür (IUCN, 2017). Literatürde TEB'in $U$. mancus üzerine toksik etkileriyle ilgili hiçbir çalışma bulunmamaktadir. Sucul organizmalar pestisitlere maruz kaldığında, oksidatif hasara yol açan reaktif oksijen türlerinin üretimi artar. $\mathrm{Bu}$ reaktif oksijen türleri, hücredeki biyomoleküllerle etkileşime girerek hücre geçirgenliğini etkiler ve onları temizleyen antioksidan enzim sistemlerini değiştirir. $\mathrm{Bu}$ nedenle, sucul ekosistemlerde ksenobiyotiklerin neden olduğu oksidatif hasarın değerlendirilmesinde, sucul organizmalardaki enzimatik ve enzimatik olmayan antioksidan sistemler ölçülür (Uçkun ve Öz, 2020). Biyolojik izleme çalışmalarında sıklıkla kullanılan biyokimyasal göstergeler, oksidatif stres ilişkili parametreler ve biyotransformasyon enzimleridir (Perendija vd., 2007). Karboksilesteraz (CaE), suda yaşayan organizmalarda ekolojik risk değerlendirme çalışmalarında kullanılan önemli esteraz enzimlerindendir (Narra vd. 2015). Oksidatif stres ilişkili parametrelerden de en yaygın kullanılanlar1; Süperoksit dismutaz (SOD), Glutatyon peroksidaz (GPx), Glutatyon Stransferaz (GST), Glutatyon redüktaz (GR), Glutatyon (GSH), Malondialdehit (MDA), Toplam antioksidan konsantrasyonu (TAC) ve Toplam oksidan konsantrasyonu (TOC)'dir.

$\mathrm{Bu}$ çalışmada, dünyada en yaygın kullanılan fungusitlerden TEB'in tehdit altındaki $U$. mancus üzerine kısa süreli (96 saat) toksik etkilerinin belirlenmesi amaçlanmıştır. $\mathrm{Bu}$ amaçla, midyelerin sindirim bezi ve solungaç dokularında oksidatif stres parametrelerinden SOD, GPx, GST, GR, GSH MDA, TAC, TOC ve Oksidatif stres indeksi (OSI) ve biyotransformasyon enzimlerinden $\mathrm{CaE}$ aktivitesindeki değişimler değerlendirilmiştir.

\section{MATERYAL VE METHOD}

\section{Hayvanlar ve deney koşulları}

Atatürk Baraj Gölü'nün çevresinde tütün, pamuk ve bakliyat tarımı yapılmaktadır (Alkan Uçkun, 2017). Tatlı su midyesi $U$. mancus örnekleri baraj gölünde tarımın en yoğun yapıldığı, dolayısıyla pestisitlerin en çok uygulandığ 
bölgelerden Temmuz 2019'da kafesli tırmık aleti yardımıyla temin edilmiştir. Toplanan midyeler, baraj gölü suyu ile doldurulmuş $15 \mathrm{~L}$ hacimli polipropilen tanklar ile uygun koşullar altında (seyyar hava motorları ile havalandırılarak) 1 saat içerisinde laboratuvara nakledilmiştir. Midyeler laboratuvara sevk edildikten sonra, damacana / pet su ile doldurulmuş $50 \mathrm{~L}$ hacimli polipropilen tanklara nakledilerek 2 hafta süreyle laboratuvar koşullarına adaptasyonları sağlanmıştır. Tanklar sürekli hava pompaları yardımıyla havalandırılmış ve midyeler 12 saat aydınlık / 12 saat karanlık döngüde, oda sıcaklığında $\left(23 \pm 1{ }^{\circ} \mathrm{C}\right.$ 'de) tutulmuştur (Uçkun ve Alkan Uçkun, 2021). Adaptasyon sürecinde midyeler, üç günde bir sucul omurgasızlar için özel üretilmiş ticari konsantre fitoplankton (Roti-Rich TM) ile beslenmiştir.

\section{Toksisite testleri}

İki haftalık adaptasyon süreci sonunda TEB'un $U$. mancus üzerindeki subletal toksik etkilerinin belirlenebilmesi amaciyla bir kontrol ve dört maruziyet grubu olmak üzere toplam beş test grubu kurulmuştur. Tüm test grupları üç tekrarlı olacak şekilde oluşturulmuştur ve bu amaçla $37 \times 24 \times 16 \mathrm{~cm}$ boyutlarında $8.5 \mathrm{~L}$ hacimli polipropilen tanklara her doz için kendine ait $5 \mathrm{~L}$ pestisit (test) solüsyonu ve 5'er adet midye bırakılarak deney düzeneği kurulmuştur. Her bir tekrar grubunda beş hayvan olacak şekilde her grupta toplam on beş hayvan kullanılmıştır $(n=15)$. Toksisite testlerinde TEB'in ticari formu (Orius ${ }^{\circledR} \quad 250$ EW， Adama, Türkiye) kullanılmıştır. Bu ticari formun aktif bileşeni $250 \mathrm{~g} \mathrm{AI} \mathrm{L}^{-1}$ olarak etiketlenmiştir. Akvaryum hava pompası yardımıyla test solüsyonu içeren tankların sürekli havalandırılması sağlanmıştır. Deney esnasında midyeler beslenmemiştir. Deneylerin başlangıcında (0. saat) YSI Pro Plus multiparametre cihazı kullanılarak, kontrol ve uygulama gruplarına ait su numunelerinin sıcaklığı, çözünmüş oksijen yüzdesi, $\mathrm{pH}$ ve iletkenliği, ölçülmüştür. Ortalama $\mathrm{pH}$, iletkenlik, sıcaklık ve çözünmüş oksijen değerleri sırasıyla 7.44 (7.23 - 7.65), $25.45 \mu \mathrm{S} \mathrm{cm}^{-1}$ (22.90 - 28.00), $22.7^{\circ} \mathrm{C}$ (21.4 - 24.0) ve $7.20 \mathrm{mg} \mathrm{L}^{-1}$ (7.00 - 7.40) olarak tespit edilmiştir. Midyeler, 96 saatlik statik yenileme test sisteminde öldürücü olmayan dört TEB konsantrasyonuna (1.5, 15, 150 ve $1500 \mu \mathrm{g}$ Aİ L ${ }^{-1}$ ) maruz bırakılmıştır. En düşük test konsantrasyonu ve diğer konsantrasyonlar geometrik olarak 10 kat fazlası olacak şekilde hesaplanmıştır. Bu aralık, TEB için Jiang vd. (2021) tarafindan belirlenen çevresel kabul edilebilir konsantrasyonlar olan $9.1 \mu \mathrm{g} \mathrm{L}^{-1} \sim 200 \mu \mathrm{g} \mathrm{L}^{-1}$ aralığ1 ve U.S.EPA (2020) tarafindan belirlenen balıklar için suda yaşam limit değeri $1135 \mu \mathrm{g} \mathrm{L}^{-1}$ dikkate alınarak belirlenmiştir.

\section{Test sularındaki gerçek TEB konsantrasyonlarının belirlenmesi}

Test sularındaki gerçek TEB konsantrasyonları, Adıyaman Üniversitesi Merkezi Araştırma Laboratuvarı'nda sıvı kromatografisi çift kütle spektrometresi (LCMSMS, Shimadzu Quadropole 8040) kullanılarak belirlenmiştir. TEB'un tutulma süresinin yaklaşık 4 dakika olduğu tespit edilmiştir. TEB konsantrasyonlarının hesaplanması için kalibrasyon eğrisi $0.5-200 \mu \mathrm{g} \mathrm{L^{-1 }}$ aralığında oluşturulmuştur. Tespit limiti ve ölçüm limiti, sirasiyla $0.95 \mu \mathrm{g} \mathrm{L}^{-1}$ ve $3.10 \mu \mathrm{g} \mathrm{L}^{-1}$ olarak hesaplanmıştır. Korelasyon katsayısı $\left(\mathrm{r}^{2}\right) 0.997$ olarak bulunmuştur. TEB, $308.24 \rightarrow 125.13$ kütle-yük oranları $(\mathrm{m} / \mathrm{z})$ ve $308.10 \rightarrow 70.13 \mathrm{~m} / \mathrm{z}$ geçişlerinde tespit edilmiştir. Tebukonazol Pestanal analitik standard,$\% \geq 98.0$ saflıkla Sigma-Supelco'dan satın alınmıştır. Her numune üç tekrarlı olarak analiz edilmiştir. LCMSMS cihaz koşulları Tablo 2'de gösterilmiştir.

\section{Biyokimyasal analizler}

Midyelerden alınan sindirim bezleri ve solungaçlar tartılarak bıçak uçlu bir homojenizatörle (Heidolph RZR 2021) $0.1 \mathrm{M}$ $\left(0.5 \mathrm{M} \mathrm{K}_{2} \mathrm{HPO}_{4}+0.5 \mathrm{M} \mathrm{KH}_{2} \mathrm{PO}_{4}\right), \mathrm{pH} 7.4$ potasyum fosfat tamponu içerisinde $(1: 4(\mathrm{w} / \mathrm{v})$ oranında) homojenize edilmiştir. Homojenatlar $16.000 \quad \mathrm{x} \quad$ g'de $\quad 4 \quad{ }^{\circ} \mathrm{C}^{\prime} \mathrm{de} \quad 20$ dakika santrifüjlenmiştir (Hettich 460 R). Elde edilen 
süpernatanlar, toplam protein konsantrasyonu ölçümleri ve enzim aktiviteleri için ependorf tüplerine aktarılmıştır. Mikroplaka okuyucu spektrofotometrede (Thermo, Varioscan Flash 2000) üç tekrarlı olacak şekilde okuma yapılmıştır. Toplam protein konsantrasyonlar1, Bradford (1976) yöntemine göre belirlenmiştir. $\mathrm{Bu}$ yöntemde, numunelerin süpernatanları seyreltildikten sonra, $5 \mu$ l'si mikroplaka kuyularına pipetlenmiş ve üzerlerine $250 \mu \mathrm{L}$ Bradford solüsyonu eklenmiştir.
Reaksiyon karışımı oda sıcaklığında karanlıkta 15 dakika inkübe edilmiştir. Renk değişimine bağlı olarak $595 \mathrm{~nm}$ dalga boyunda absorbans değeri ölçülmüştür. Daha sonra seyreltme faktörü dikkate alınarak süpernatanlardaki toplam protein değerleri hesaplanmıştır. Tüm enzimlerin aktiviteleri, toplam protein seviyeleri ölçüldükten sonra spesifik aktivite (nmol $\mathrm{min}^{-1}$ mg toplam protein ${ }^{-1}$ ) cinsinden ifade edilmiştir.

Tablo 2. LCMSMS' in enstrümantal koşulları

\begin{tabular}{|ll|}
\hline Cihaz modeli & Shimadzu LCMSMS-8040 \\
\hline Mobil faz A & $1 \mathrm{mM}$ amonyum asetat \% 100 su içinde \\
\hline Mobil faz B & $\% 100$ metanol \\
\hline Kolon & Inertsil ODS-4 (2.1 mm I.D. $\times 50 \mathrm{~mm} \mathrm{L,} 3 \mu \mathrm{m})$ \\
\hline Kolon fırın sıcaklığı & $40{ }^{\circ} \mathrm{C}$ \\
\hline Akış hızı & $0.4 \mathrm{~mL}$ dak $^{-1}$ \\
\hline Arayüz akımı & $4.5 \mathrm{kV}$ \\
\hline Püskürtme gazı akış hızı & $3 \mathrm{~mL} \mathrm{dak}$ \\
\hline Kurutma gazı akış hızı & $15 \mathrm{~mL} \mathrm{dak}^{-1}$ \\
\hline DL sıcaklığı & $250{ }^{\circ} \mathrm{C}$ \\
\hline HB sıcaklığı & $400{ }^{\circ} \mathrm{C}$ \\
\hline
\end{tabular}

$\mathrm{CaE}$ aktivitesini belirlemek için Santhoshkumar ve Shivanandappa (1999) tarafından önerilen spektrofotometrik yöntem mikroplaka okuyucu sistemine uyarlanmıştır. Substrat olarak $26 \mathrm{mM} \% 96$ etanol içinde hazırlanan p-nitrofenol asetat (PNPA) kullanılmıştır. $\mathrm{Bu}$ amaçla $5 \mu \mathrm{L}$ numune ve 250 $\mu \mathrm{L}$ Tris tamponu (0.05 M, pH 7.4) mikroplaka kuyularına pipetlenmiş ve $25^{\circ} \mathrm{C}$ de 3 dakika inkübe edilmiştir. Ardından kuyucuklara $5 \mu \mathrm{L}$ PNPA eklenerek $0.5 \mathrm{mM}$ nihai konsantrasyon elde edilmiş ve $405 \mathrm{~nm}$ 'de 2 dakika süreyle distile suya karşı absorbans değerleri ölçülmüştür. Spesifik CaE aktivitesi nmol min ${ }^{-1}$ mg protein $^{-1}$ olarak hesaplanmıştır (PNPA için $\left.405 \mathrm{~nm} \mathrm{C}=1830 \mathrm{M}^{-1} \mathrm{~cm}^{-1}\right)$.

SOD aktivitesi, Sun vd. (1988) tarafından geliştirilen yönteme göre ölçülmüştür. Reaksiyonda ksantinin ksantin oksidaz ile etkileşimi sonucu süperoksit radikalleri oluşmuştur. $\mathrm{Bu}$ süperoksit radikalleri nitrobluetetrazolium ile etkileşime girerek 560 nm'de spektrofotometrik olarak değerlendirilebilen renkli formazan boyası oluşturur.

GPx aktivitesinin ölçümünde Bell ve arkadaşlarının (1985) metodu mikroplaka okuyucu sistemine uyarlanmıştır. Bu yöntemde substrat olarak hidrojen peroksit $\left(\mathrm{H}_{2} \mathrm{O}_{2}\right)$, katalaz inhibitörü olarak sodyum azit $\left(\mathrm{NaN}_{3}\right)$ kullanılmıştır. $10 \mu \mathrm{L}$ süpernatan ve $60 \mu \mathrm{L} 1 \mathrm{mM}$ GSH, $0.1 \mathrm{mM}$ NADPH, 0.32 birim GSHredüktaz, $1 \mathrm{mM}$ EDTA, $2 \mathrm{mM} \mathrm{NaN}_{3}$ içeren 50 $\mathrm{mM} \quad \mathrm{pH} \quad 7.4$ fosfat tamponu mikroplaka kuyularına pipetlendikten sonra bu karışım $20^{\circ} \mathrm{C}$ 'de 6 dakika süreyle inkübe edilmiştir. İnkübasyondan sonra kuyucuklara $30 \mu \mathrm{L} 1.67$ $\mathrm{mM} \mathrm{H}_{2} \mathrm{O}_{2}$ pipetlenerek reaksiyon başlatılmış, NADPH oksidasyonuna bağlı absorbans değişikliğii, $25^{\circ} \mathrm{C}^{\prime}$ de 3 dakika boyunca $340 \mathrm{~nm}$ 'de kaydedilmiştir. Spesifik GPx aktivitesi nmol 
$\min ^{-1} \mathrm{mg}$ protein $^{-1}$ olarak hesaplanmıştır (NADPH için $\epsilon=6220 \mathrm{M}^{-1} \mathrm{~cm}^{-1}, 340 \mathrm{~nm}$ 'de).

GST aktivitesinde, Habig ve arkadaşlarının (1974) yöntemi mikroplaka sistemine uyarlanarak ölçülmüştür. Substrat olarak CDNB (1-kloro-2,4-dinitrobenzen), kofaktör olarak GSH kullanılmıştır. Mikroplaka kuyularına 10 $\mu \mathrm{L}$ süpernatan, $100 \mu \mathrm{L}$ fosfat tamponu, $100 \mu \mathrm{L}$ GSH ve $10 \mu \mathrm{L}$ CDNB karışımı pipetlenmiştir. Karışım mikroplaka okuyucuya yerleştirildikten sonra 15 saniye karıştırılmış ve 344 nm'de absorbanstaki değişim $25^{\circ} \mathrm{C}$ 'de 2 dakika süreyle kaydedilmiştir.

GR aktivitesi, Cribb vd. (1989) tarafindan geliştirilen yöntemin mikroplaka okuyucu sistemine uyarlanmasıyla belirlenmiştir. Reaksiyon, 5,5'-ditiyobis-(2-nitrobenzoik asit) (DTNB), NADPH ve numuneden oluşan reaksiyon çözeltisine oksitlenmiş glutatyon (GSSG) eklenerek başlatılmıştır. Reaksiyon sırasında GSSG'den GSH oluşumuna bağl1 olarak DTNB miktarındaki azalmaya göre spesifik GR aktivitesi hesaplanmıştır.

GSH seviyesi, Moron ve arkadaşlarının (1979) metodunun mikroplaka okuyucu sistemine uyarlanmış haline göre belirlenmiştir. GSH standart eğrisine karşı örneklerin 412 nm'deki absorbans değeri okunarak GSH düzeyi nmol GSH mg protein ${ }^{-1}$ olarak hesaplanmıştır.

MDA konsantrasyonu, Placer vd. (1966) tarafından bazı modifikasyonlarla tarif edildiği gibi tiyobarbitürik asit reaktif madde analizine dayalı olarak ölçülmüştür. MDA içerikleri, standart olarak malondialdehit bis (dietil asetal) kullanılarak belirlenmiştir. Absorbans değeri $532 \mathrm{~nm}$ 'de okunmuş ve MDA konsantrasyonu, nmol MDA mg protein $^{-1}$ olarak ifade edilmiştir. TAC ve TOC analizleri ticari test kitleri (Reel Assay Diagnostics) kullanılarak yapılmıştır (Erel, 2005). TAC analizinin prensibi, koyu mavi-yeşil stabil 2,2'-azino-di-3-etilbenztiazolin sülfonat (ABTS) radikalinin numunedeki antioksidanlar tarafından renksiz indirgenmiş ABTS formuna dönüştürülmesine dayanmaktadır. Örnekteki antioksidanların miktarı, bu rengin yokluğu ile ilişkilidir. Analiz, Trolox eşdeğeri olarak bilinen bir E vitamini analoğu olan stabil bir antioksidan standart solüsyon kullanılarak kalibre edilmiştir. TAC seviyeleri, 660 nm'de end-point ölçümü sonucu absorbans değerlerinden hesaplanmış ve $\mu \mathrm{mol}$ Trolox eşdeğerleri $\mathrm{L}^{-1}$ olarak ifade edilmiştir. TOC testinin prensibi, numunede bulunan oksidanların $\mathrm{Fe}^{2+}$ iyon-şelatör kompleksini $\mathrm{Fe}^{3+}$ iyonuna oksitlemesidir. Asidik bir ortamda $\mathrm{Fe}^{3+}$ iyonu kromojen ile renkli bir kompleks oluşturur ve renk yoğunluğu spektrofotometrik olarak belirlenir. Renk yoğunluğu, numunedeki toplam oksidan molekül miktarı ile orantılıdır. Tespit için kalibrasyon, hidrojen peroksit ile gerçekleştirilmiştir. TOC seviyeleri, $530 \mathrm{~nm}$ 'de end-point ölçümü sonucu absorbans değerlerinden hesaplanmış ve mmol $\mathrm{H}_{2} \mathrm{O}_{2}$ eşdeğerleri $\mathrm{L}^{-1}$ olarak ifade edilmiştir. Oksidatif stres indeksini (OSI) hesaplamak için [OSI=TOC/(TACx10)] formülü kullanılmış ve sonuçlar yüzde olarak ifade edilmiştir (Erel, 2005).

\section{İstatistiksel analiz}

Verilerin istatistiksel analizi SPSS 22 (ABD) yazılım paketi ile gerçekleştirilmiştir. ShapiroWilk ve Levene testleri kullanılarak, tüm değişkenler sırasıyla normallik ve homojenlik açısından analiz edilmiştir. Gruplar arasındaki farkı test etmek için Kruskal-Wallis testi kullanılmıştır. Tüm veriler ortalama değer \pm standart hata olarak sunulmuştur. Tüm analizler için $p<0.05$ ve $p<0.01$ istatistiksel olarak anlamlı kabul edilmiştir.

\section{BULGULAR}

\section{Test sularındaki gerçek TEB konsantrasyonları}

LCMSMS analizinden elde edilen test sularındaki gerçek TEB konsantrasyonları Tablo 3'de gösterilmiştir. 24 saat sonraki gerçek konsantrasyonların, nominal konsantrasyonlar dan yaklaşık \%5-16 arasında daha düşük olduğu belirlenmiştir. Nominal ve gerçek 
konsantrasyonlar arasındaki bu farklılıklar, yüzey aktif maddeler, çözücüler ve pestisitlerin ticari formülasyonlarında kullanılan koruyucular gibi diğer bileşiklerden kaynaklanıyor olabilir (Korkmaz vd., 2018).

Tablo 3. Test sularındaki gerçek TEB konsantrasyonları (Ortalama \pm standart hata $(\mathrm{N}=3)$ ).

\begin{tabular}{|ccccc|}
\hline $\begin{array}{c}\text { Nominal } \\
\text { konsantrasyonlar } \\
\left(\mu g \mathrm{~L}^{-1}\right)\end{array}$ & $\begin{array}{c}\text { Uygulamadan önce } \mathbf{( 0 .} \\
\text { Saat) }\end{array}$ & $\begin{array}{c}\text { Geri kazanım } \\
(\boldsymbol{\%})\end{array}$ & $\begin{array}{c}\text { Uygulamadan sonra } \\
(\mathbf{2 4} \text {. saat) }\end{array}$ & $\begin{array}{c}\text { Geri kazanım } \\
(\boldsymbol{\%})\end{array}$ \\
\hline Kontrol & 0 & - & 0 & - \\
\hline $\mathbf{1 . 5}$ & $1.53 \pm 0.05$ & $\% 102.00$ & $1.26 \pm 0.09$ & $\% 84.00$ \\
\hline $\mathbf{1 5}$ & $14.95 \pm 0.50$ & $\% 99.67$ & $13.84 \pm 0.19$ & $\% 92.27$ \\
\hline $\mathbf{1 5 0}$ & $156.66 \pm 1.91$ & $\% 104.44$ & $136.99 \pm 3.61$ & $\% 91.33$ \\
\hline $\mathbf{1 5 0 0}$ & $1502.14 \pm 13.17$ & $\% 100.14$ & $1429.55 \pm 32.21$ & $\% 95.30$ \\
\hline
\end{tabular}

\section{Biyokimyasal yanıtlar}

96 saatlik TEB maruziyeti sonrası U. mancus'un solungaç ve sindirim bezlerindeki biyokimyasal yanıtlar Tablo 4'de gösterilmiştir. CaE aktivitesi her iki dokuda da doza bağımlı olarak düşüş göstermiştir. Solungaç dokusunda sadece 150 $\mu \mathrm{g} \mathrm{L}^{-1}$ ve $1500 \mu \mathrm{g} \mathrm{L}^{-1}$ kosantrasyonlarındaki düşüşler kontrole göre anlamlıyken sindirim bezinde tüm konsantrasyonlardaki düşüşler anlamlı olmuştur ( $p<0.05, p<0.01)$. En yüksek TEB konsantrasyonunda $\left(1500 \mu \mathrm{g} \mathrm{L}^{-1}\right) \mathrm{CaE}$ inhibisyonları, solungaçta kontrole göre yaklaşık olarak $\% 35$, sindirim bezinde ise $\% 48$ olarak hesaplanmıştır. SOD aktivitelerinde hem solungaçta hem de sindirim bezinde doza bağımlı artış gözlenmiştir. Solungaçta en fazla artış en yüksek TEB uygulama dozunda (1500 $\left.\mu \mathrm{g} \mathrm{L}^{-1}\right)$ görülürken, sindirim bezinde $150 \mu \mathrm{g} \mathrm{L}^{-1}$ dozunda görülmüştür. Her iki dokuda da $1.5 \mu \mathrm{g}$ $\mathrm{L}^{-1}$ dozu hariç bütün dozlardaki artışlar kontrole göre anlamlı olmuştur ( $p<0.05, p<0.01)$. GPx aktivitesi de solungaç ve sindirim bezlerinde kontrole göre artmıştır. İki dokuda da en fazla artış $150 \mu \mathrm{g} \mathrm{L}^{-1}$ dozunda olmuştur ve kontrole göre anlamlıdır $(p<0.05, p<0.01)$. GST aktivitesi solungaç ve sindirim bezinin her iksinde de kontrole göre artış göstermiştir ancak bu artış solungaçta uygulanan TEB konsantrasyonuyla koordineli iken sindirim bezinde konsantrasyona bağımlı olmamıştır. Solungaçta $1.5 \mu \mathrm{g} \mathrm{L}^{-1}$ dozu hariç bütün dozlardaki GST aktivitesi artışları kontrole göre anlamlı bulunmuştur ( $p<0.05, p<0.01)$. Sindirim bezinde ise $1500 \mu \mathrm{g} \mathrm{L}^{-1}$ dozundaki artış kontrole göre $p<0.05$ ve $p<0.01$ düzeylerinde önemliyken $1.5 \mu \mathrm{g} \mathrm{L}^{-1}$ ve $150 \mu \mathrm{g}$ $\mathrm{L}^{-1}$ dozlarındaki artışlar sadece $p<0.05$ düzeyinde önemli, $15 \mu \mathrm{g} \mathrm{L}^{-1}$ dozundaki artış önemsiz bulunmuştur. GR aktivitesi solungaç ve sindirim bezinde tüm TEB dozlarında kontrole göre inhibisyona uğramıştır, ancak bu inhibisyonlar doza bağımlı olmamıştır. Sindirim bezindeki inhibisyonların tamamı kontrole göre önemliyken $(p<0.05, p<0.01)$ solungaçta 150 $\mu \mathrm{g} \quad \mathrm{L}^{-1}$ dozundaki inhibisyon $p<0.05$ seviyesinde, $1500 \mu \mathrm{g} \mathrm{L}^{-1}$ dozundaki inhibisyon $p<0.05, p<0.01$ seviyesinde önemli bulunmuştur. En fazla inhibisyon, solungaç ve sindirim bezinde sirasiyla $\% 60$ ve $\% 50$ oranlarında $1500 \mu \mathrm{g} \mathrm{L}^{-1}$ uygulama dozunda olmuştur. GSH düzeyi solungaç ve sindirim bezinde TEB uygulamasına bağlı olarak kontrole göre düşmüştür. $\mathrm{Bu}$ düşüşler, solungaçta $1.5 \mu \mathrm{g} \mathrm{L}^{-1}$ ve $15 \mu \mathrm{g} \mathrm{L}^{-1}$ dozlarında kontrole göre önemsizken, $150 \mu \mathrm{g} \mathrm{L}^{-1}$ dozunda $p<0.05$ seviyesinde, $1500 \mu \mathrm{g} \mathrm{L}^{-1}$ dozunda ise $p$ $<0.05, p<0.01$ seviyelerinde önemli bulunmuştur. Sindirim bezinde ise tüm uygulama dozlarında kontrole göre $p<0.05, p<$ 0.01 seviyelerinde önemli bulunmuştur. MDA seviyelerinde sadece $150 \mu \mathrm{g} \mathrm{L}^{-1}$ ve $1500 \mu \mathrm{g} \mathrm{L}^{-1}$ dozlarında kontrole göre önemli artışlar 
olmuştur. $\mathrm{Bu}$ fark sindirim bezinde $p<0.05, p<$ 0.01 seviyelerinde önemliyken solungaçta $p<$ 0.05 seviyesinde önemlidir. TAC seviyesi, hem solungaçta hem de sindirim bezinde bütün TEB uygulama dozlarında doza bağımlı olarak ve kontrole göre önemli derecede düşmüştür ( $p<$ $0.05, p<0.01)$. TOC seviyesi ise solungaçta bütün dozlarda, sindirim bezinde sadece $150 \mu \mathrm{g}$ $\mathrm{L}^{-1}$ ve $1500 \mu \mathrm{g} \mathrm{L}^{-1}$ dozlarında kontrole göre önemli oranda artmıştır $(p<0.05, p<0.01)$. Oksidatif stres indeksinde (OSI) her iki dokuda da bütün dozlarda kontrole göre önemli artışlar olmuştur.

Tablo 4. 96 saat TEB maruziyeti sonrası U. mancus'un solungaç ve sindirim bezlerindeki biyokimyasal yanıtlar: (Enzim

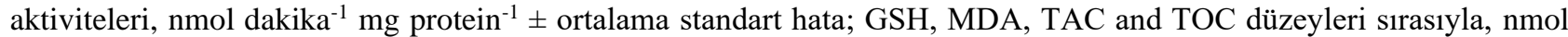

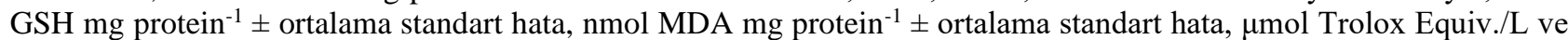
mmol $\mathrm{H}_{2} \mathrm{O}_{2}$ Equiv./L; OSI ise, $\mathrm{AU}$ (Arbitrary Unit) olarak ifade edilmiștir.) $(\mathrm{n}=15)$.

\begin{tabular}{|c|c|c|c|c|c|c|}
\hline \multicolumn{7}{|c|}{ Konsantrasyonlar } \\
\hline & Biyobelirteçler & Control & $1.5 \mu \mathrm{g} \mathrm{L}-1$ & $15 \mu \mathrm{g} \mathrm{L}-1$ & $150 \mu \mathrm{g} \mathrm{L}-1$ & $1500 \mu \mathrm{g} \mathrm{L}-1$ \\
\hline \multirow{10}{*}{ Solungaç } & $\mathrm{CaE}$ & $307.54 \pm 14.45$ & $261.30 \pm 33.17$ & $238.02 \pm$ & $203.77 \pm 9.08 * *$ & $200.11 \pm 14.32 * *$ \\
\hline & SOD & $5.38 \pm 0.19$ & $6.81 \pm 0.38$ & $7.93 \pm 0.66^{* *}$ & $8.15 \pm 0.21 * *$ & $10.34 \pm 0.50 * *$ \\
\hline & GPx & $15.31 \pm 0.75$ & $19.24 \pm 0.58$ & $21.15 \pm 1.59 *$ & $24.72 \pm 1.96 * *$ & $22.35 \pm 1.57 * *$ \\
\hline & GST & $35.44 \pm 2.77$ & $44.30 \pm 1.88$ & $48.57 \pm 2.69 * *$ & $51.32 \pm 1.54 * *$ & $52.55 \pm 2.75 * *$ \\
\hline & GR & $26.60 \pm 1.26$ & $16.69 \pm 3.98$ & $17.11 \pm 3.29$ & $16.15 \pm 1.55^{*}$ & $10.77 \pm 1.05 * *$ \\
\hline & GSH & $0.21 \pm 0.01$ & $0.15 \pm 0.03$ & $0.15 \pm 0.01$ & $0.14 \pm 0.01 *$ & $0.09 \pm 0.01 * *$ \\
\hline & MDA & $0.95 \pm 0.08$ & $1.44 \pm 0.26$ & $1.45 \pm 0.02$ & $1.52 \pm 0.07 *$ & $1.56 \pm 0.11 *$ \\
\hline & TAC & $1.91 \pm 0.01$ & $1.62 \pm 0.02 * *$ & $1.56 \pm 0.02 * *$ & $1.09 \pm 0.01 * *$ & $1.00 \pm 0.02 * *$ \\
\hline & TOC & $1.27 \pm 0.03$ & $2.73 \pm 0.09 * *$ & $2.57 \pm 0.03 * *$ & $2.45 \pm 0.01 * *$ & $3.78 \pm 0.11 * *$ \\
\hline & OSI & $0.064 \pm 0.002$ & $0.17 \pm 0.008 * *$ & $0.16 \pm 0.002 * *$ & $0.22 \pm 0.002 * *$ & $0.38 \pm 0.004 * *$ \\
\hline \multirow{10}{*}{$\begin{array}{c}\text { Sindirim } \\
\text { Bezi }\end{array}$} & $\mathrm{CaE}$ & $1036.69 \pm 33.20$ & $765.46 \pm 82.15^{* *}$ & $640.27 \pm 51.58 * *$ & $611.48 \pm 31.64 * *$ & $543.07 \pm 23.45 * *$ \\
\hline & SOD & $6.45 \pm 0.14$ & $7.55 \pm 0.47$ & $8.33 \pm 0.44^{* *}$ & $9.00 \pm 0.33 * *$ & $8.15 \pm 0.04^{* *}$ \\
\hline & GPx & $9.81 \pm 0.39$ & $11.48 \pm 0.75$ & $12.88 \pm 0.41 * *$ & $12.98 \pm 0.37 * *$ & $12.51 \pm 0.10 * *$ \\
\hline & GST & $30.69 \pm 1.45$ & $48.42 \pm 6.33 *$ & $42.63 \pm 3.44$ & $50.33 \pm 3.06 *$ & $83.56 \pm 4.59 * *$ \\
\hline & GR & $16.73 \pm 0.77$ & $9.44 \pm 0.54 * *$ & $9.31 \pm 0.64 * *$ & $9.57 \pm 0.59 * *$ & $8.32 \pm 0.50 * *$ \\
\hline & GSH & $0.13 \pm 0.002$ & $0.12 \pm 0.001 * *$ & $0.11 \pm 0.002 * *$ & $0.11 \pm 0.001 * *$ & $0.09 \pm 0.001 * *$ \\
\hline & MDA & $0.60 \pm 0.03$ & $0.77 \pm 0.05$ & $0.82 \pm 0.10$ & $1.07 \pm 0.08 * *$ & $1.30 \pm 0.12 * *$ \\
\hline & TAC & $1.98 \pm 0.04$ & $1.39 \pm 0.01 * *$ & $0.87 \pm 0.03 * *$ & $0.84 \pm 0.04 * *$ & $0.77 \pm 0.06^{* *}$ \\
\hline & TOC & $0.38 \pm 0.08$ & $0.52 \pm 0.02$ & $0.56 \pm 0.04$ & $0.72 \pm 0.02 * *$ & $1.22 \pm 0.02 * *$ \\
\hline & OSI & $0.02 \pm 0.005$ & $0.03 \pm 0.001 *$ & $0.04 \pm 0.002 * *$ & $0.06 \pm 0.002 * *$ & $0.12 \pm 0.001 * *$ \\
\hline
\end{tabular}

*: $p<0.05$, kontrol grubu ile karşılaştırıldığında istatistiksel önemi göstermektedir

**: $p<0.01$, kontrol grubu ile karşılaştırıldığında istatistiksel önemi göstermektedir

\section{TARTIȘMA}

Pestisitler de dahil olmak üzere birçok ksenobiyotik, hücre zarı boyunca elektron taşınmasının bozulması, Fenton reaksiyonunun kolaylaştırılması, antioksidan enzimlerin inaktivasyonu ve serbest radikal süpürücülerin tükenmesi gibi çeşitli biyokimyasal mekanizmalarla reaktif oksijen türlerinin üretimini tetikleyebilir (Winston ve Di Giulio,
1991). Bu reaktif oksijen türlerini temizlemek için organizmalarda antioksidan savunma sistemleri geliştirilmiştir ve bu antioksidan sistemlerin aktivasyon / inhibisyon düzeyi değerlendirilerek ksenobiyotiklerin organizmaya verdiği oksidatif hasar tahmin edilmektedir (Di Giulio ve Meyer, 2008). Bu çalışmada, TEB'in tatlı su midyelerine toksik etkileri, solungaç ve sindirim bezlerinde oksidatif stres parametreleri, antioksidan enzim seviyeleri ve 
biyotransformasyon enzimindeki değişimler gözlemlenerek değerlendirilmiştir.

Çalışmamızda önemli bir biyotransformasyon enzimi olan $\mathrm{CaE}$, kontrole göre inhibisyona uğramıştır. CaE'ler, karboksilik esterler, tiyoesterler, amidler, karbamatlar ve çeşitli ksenobiyotikler gibi substratların hidrolizini katalize eden esteraz ailesinin üyeleridir. $\mathrm{CaE}^{\prime}$ ler lipid metabolizması, ön ilaç aktivasyonu, pestisit metabolizması ve ftalatların hidrolizi gibi önemli fizyolojik süreçlerde yer alırlar (Lenfant vd., 2012). CaE aktivitesindeki inhibisyonlar, organizmanın strese adaptasyonu olarak düşünülebilir (De Lima vd., 2013). Sindirim bezleri, oral yolla alınabilen esterleri içeren yüksek konsantrasyonlarda toksinler nedeniyle CaE ekspresyonu için özellikle önemlidir (Ross vd., 2010). CaE'nin inhibisyonu, TEB maruziyetinin midyelerde normal detoksifikasyon fonksiyonlarını etkileyebileceğini düşündürmektedir. Bizim sonuçlarımıza benzer olarak, literatürde, çeşitli sucul canlılarda pestisit maruziyetine bağlı olarak $\mathrm{CaE}$ inhibisyonu olduğuna dair çalışmalar mevcuttur (Denton vd., 2003; Wheelock vd., 2005; Uçkun ve Öz, 2020; Uçkun vd., 2021). SOD, organizmayı oksidatif stresten korumak için süperoksit anyonlarını ve hidrojen peroksiti temizleyen antioksidan savunma sisteminin önemli bir bileşenidir. Çalışmamızda önemli ölçüde artan SOD aktivitesi, ROS'u ortadan kaldırmak ve oksidatif stresi azaltmak için antioksidan savunma sisteminin aktive olduğunu göstermektedir (Van Rensburg vd., 1995). Sonuçlarımıza paralel olarak, Cao vd. (2018) larva zebra balıklarına 4 gün boyunca $0.05 \mathrm{mg} / \mathrm{L}$ dozunda azoksistrobin uygulamasına bağlı olarak SOD aktivitesinde önemli bir artış gözlemlemiştir. Uçkun ve Öz (2020) konazol grubu pestisitlerden olan penkonazolü 96 saat boyunca uyguladikları kerevitlerin hepatopankreas dokularında SOD aktivitesinin kontrole göre önemli oranda arttığını gözlemlemiştir. GPx, GSH varlığında hidrojen peroksit ve lipid peroksit düzeylerinin azalmasını katalize eden bir antioksidan enzimdir (Moreno vd., 2005). GPx enzimindeki inhibisyon, antioksidan sistemin pestisitin yıkıcı etkisini önlemedeki başarısızlığını gösterebilir veya hücrelerde oluşan reaktif oksijen türlerinin bu enzimin sentezine doğrudan etkisi ile ilişkili olabilir (Yonar vd., 2014). Bu açıdan bakıldığında, çalışmamızda gözlemlenen GPx artış1, hücrede TEB'un neden olduğu oksidatif hasara karşı GPx'in koruyucu rolünü yansıtabilir. Bizim sonuçlarımıza benzer olarak Jiang vd. (2018), yetişkin zebra balıklarında 24 saat azoxystrobine maruz kalmanın bir sonucu olarak tüm doz gruplarında GPx aktivitesinin önemli ölçüde arttığını bildirmişlerdir. GST, Faz I detoksifikasyon ürünlerini suda daha çözünür bir forma dönüştüren konjugasyon işlevini yerine getiren bir Faz II detoksifikasyon enzimidir. Bu sayede reaktif serbest radikal birikimini ve hücresel hasarı önler (Chahine ve O'Donnell, 2011). Çalışmamızda TEB konsantrasyonundaki artışa bağlı olarak GST aktivitesinin artması, TEB'in solungaç ve sindirim bezinde GST üzerine doza bağlı toksik etkiye sahip olduğunu ve GST'nin de bu TEB'i detoksifiye etmek için aktivitesini arttırdığını düşündürmektedir. Aynı zamanda GST aktivitesindeki artış, $\mathrm{H}_{2} \mathrm{O}_{2}$ 'nin artan detoksifikasyonuna veya TEB'in faz II biyotransformasyonunun bir parçası olarak konjugasyon işlevine bağlanabilir (Hemalatha vd., 2015). Benzer şekilde, Korkmaz vd. (2018), zebra balıklarında (Danio rerio) 96 saat maruziyetten sonra GST'nin fosalon bazlı ve sipermetrin bazlı pestisitler tarafindan indüklendiğini gözlemlemiştir. Literatürde pestisit uygulanan sucul canlilarda GST aktivitesinin arttığını ortaya koyan birçok çalışma bulunmaktadır (Sayeed vd., 2003; Oruç, 2010; Moreira vd., 2010; Uçkun ve Öz, 2021; Uçkun ve Özmen 2021). GR, hücrede genel homeostatik oksido indirgeyici denge sağlayarak azaltılmış glutatyon durumunu korur, böylece hücreleri reaktif oksijen metabolitlerine karş1 korur (Djordjevic vd., 2010). Çalışmamızda GR'nin inhibe olmasının nedeni, yüksek konsantrasyonlarda TEB uygulamasından dolayı 
meydana gelen oksidatif stres olabilir. GR, GSSG'den GSH'nin geri dönüşümüne katılarak hücreye antioksidan koruma sağlar (Elia vd., 2003). GR'nin etkisi ile hücre içindeki GSH ve GSSG arasındaki denge, GSH'nin geri dönüşümü ile sağlanır (Schafer ve Buettner, 2001). Bu nedenle GSH, GSSG ve toplam glutatyon içerikleri de azalır, dolayısıyla glutatyon içeren savunma sistemi yüksek doz TEB maruziyetine karşı zayıf kalır. GSH, pestisit maruziyeti nedeniyle ROS üretimini kontrol etmede rol oynayan enzimatik olmayan bir antioksidandir (Parke ve Piotrowski, 1996). Oksijen radikallerine maruz kalmak GSH düzeyinde artışa neden olur (Dickinson ve Forman, 2002). Çalışmamızda GSH düzeyindeki düşüş, TEB uygulamasının neden olduğu oksidatif stres koşullarında tüketilen GSH'nin üretilen GSH'den daha hızlı olduğunu göstermektedir. Lipid peroksidasyonunun en önemli ürünlerinden biri olan MDA, hücre zarlarındaki iyon geçirgenliğini bozar, zardaki bileşiklerin çapraz bağlanmasına yol açar ve enzimlerin aktivitesini bozar (Mercan, 2004). Çalışmamızda, uygulanan

TEB konsantrasyonunun artması nedeniyle MDA düzeyindeki artışlar, MDA'nın lipid peroksidasyonunun son ürünü olması nedeniyle, TEB'in biyomoleküllerde önemli oksidatif hasara neden olduğunu ve yüksek düzeyi, serbest radikallerin aşırı üretildiğini ve hücre zarlarına hasarının olduğunu göstermektedir (Abhijith vd., 2016).

TAC, biyolojik numunelerde toplam antioksidan kapasiteyi bulmak için kullanılan bir test solüsyonu tarafindan temizlenen serbest radikal miktarının bir ölçüsüdür. TOC ise tüm antioksidan sistemin serbest oksijen radikallerini temizleme yeteneğini ölçmek için kullanılan bir parametredir. TAC ve TOC, organizmalarm ksenobiyotiklerin neden olduğu oksidatif strese karşı biyolojik tepkilerini tahmin etmede faydalı biyobelirteçlerdir (Pinchuk vd., 2012; Regoli, 2000). TAC'nin enzimatik ve enzimatik olmayan antioksidanların toplamı olduğu varsayılmaktadır (Mahfouz vd., 2009). Çalışmamızda TAC seviyesinin TEB uygulamasına bağlı olarak düşmesinin nedeni, TEB 'in solungaç ve sindirim bezinde yarattığ oksidatif strese tepki olarak enerji tüketimi olarak açıklanabilir. Bulgularımıza paralel olarak Hamed vd., (2020), mikroplastiklere maruz bıraktıkları Oreochromis niloticus'ta doz arttıkça TAC seviyesinin düştügünü gözlemlemiştir. Uçkun ve Uçkun (2021), su ve sedimentinde yoğun metal bulunan bölgelerden topladıkları sazan balıklarının karaciğerinde TAC seviyesinin temiz bölgelere göre daha düşük olduğunu bildirmiştir. TOC, bir kimyasal indükleyicinin organizmada oluşturduğu toplam oksidan molekül miktarını yansitır. Çalışmamızda TOC seviyesinin artması, TEB'in oksijen radikallerine bağlanarak onları hücrede ROS üretimini artıran ve antioksidan enzimleri inhibe eden çeşitli reaktif metabolitlere dönüştürmesine yorulabilir (Vahdati Hassani vd., 2018). OSI, organizmada oksidatif strese neden olan serbest radikal oluşturucu ajanlar ile bunlara karşı antioksidan savunma sistemleri arasındaki ilişkinin derecesini gösteren bir göstergedir (Sayed ve Khalil, 2016). Çalışmamızda uygulanan TEB konsantrasyonu arttıkça OSI değerinin kontrole göre anlamlı olarak artması TAC ve TOC bulgularımızı desteklemektedir.

\section{SONUÇ}

Sonuç olarak, TEB'in, antioksidan enzimlerin aktivitesini bozarak ve GSH, MDA, TAC ve TOC seviyelerini değiştirerek oksidatif stresi indüklediği söylenebilir. Ayrıca TEB uygulaması nedeniyle $\mathrm{CaE}$ inhibisyonun gözlenmesi, TEB'in kısa süreli uygulamalarda biyotransformasyon sistemini uyarabileceği bilgisini vermektedir. Literatürde $U$. mancus üzerine pestisitlerden penkonazol (Yoloğlu, 2019) ve imidaklopritin (Uçkun ve Alkan Uçkun, 2021) toksik etkilerine yönelik çalışmalar mevcuttur ancak TEB'e ilişkin bir çalışmaya rastlanmamıştır. $\mathrm{Bu}$ bağlamda 
çalışmamız TEB'in hedef dişı organizmalar üzerindeki toksik etkileri ile ilgili literatüre önemli bir katkı sağlamıştır. Sonuçlarımız, TEB'in düşük konsantrasyonlarda bile $U$. mancus üzerinde önemli toksik etkilere sahip olduğunu göstermektedir. $\mathrm{Bu}$ nedenle TEB'in kullanıldığ 1 tarım alanlarına yakın tatlı sularda yaşayan $U$. mancus 'un tehdit altında olabileceğini söyleyebiliriz.

\section{ACIKLAMALAR}

Etik beyan: Çalışma, tatlısu midyesi (molluscabivalvia) ile yapıldı. Tatlı su midyeleri omurgasız hayvanlar grubuna girdiğinden dolayı bu gruptaki hayvanlara etik kurul raporu gerekmemektedir.

Çıkar çatışması: Yazar, bu makale için gerçek, potansiyel veya algılanan bir çıkar çatışması olmadığını beyan etmektedir.

\section{KAYNAKLAR}

Abhijith, B.D., Ramesh, M., Poopal, R.K. (2016). Responses of metabolic and antioxidant enzymatic activities in gill, liver and plasma of Catla catla during methyl parathion exposure. The Journal of Basic and Applied Zoology, 77, 31-40. https://doi.org/10.1016/j.jobaz.2015.11.002

Allen, D., Wilson, D., Drew, R., Perfect, J. (2015). Azole antifungals: 35 years of invasive fungal infection management. Expert Review of Anti-infective Therapy, 13(6),

https://doi.org/10.1586/14787210.2015.1032939

Alkan Uçkun, A. (2017). Ecotoxicological evaluation of pesticide pollution in Ataturk dam Lake (Euphrates River), Turkey. Turkish Journal of Fisheries and Aquatic Sciences, 17(2), 313-321. https://doi.org/10.4194/1303-2712-v17_2_10

Bell, J.G., Cowey, C.B., Adro, J.W., Shanks, A.M. (1985). Some effects of vitamine and selenium deprivation on tissue enzyme levels and indices of tissue peroxidation in rainbow trout (Salmo gairdneri). British Journal of Nutrition, 53, 149-57. https://doi.org/10.1079/BJN19850019

Bhagat, J., Singh, N., Nishimura, N., Shimada, Y. (2021). A comprehensive review on environmental toxicity of azole compounds to fish. Chemosphere, 262, 128335. https://doi.org/10.1016/j.chemosphere. 2020.128335

Bradford, M.M. (1976). A rapid and sensitive method for the quantitation of microgram quantities of protein utilizing the principle of protein-dye binding. Analytical Biochemistry, 72, 248-54. https://doi.org/ $\underline{10.1016 / 0003-2697(76) 90527-3}$
Cao, F., Wu, P., Huang, L., Li, H., Qian, L., Pang, S., Qiu, L. (2018). Short-term developmental effects and potential mechanisms of azoxystrobin in larval and adult zebrafish (Danio rerio). Aquatic Toxicology, 198, 129-40. https://doi.org/10.1016/j. aquatox.2018.02.023

Chahine, S., O'Donnell, M.J. (2011). Interactions between detoxification mechanisms and excretion in malpighian tubules of Drosophila melanogaster. Journal of Experimental Biology, 214, 462-8. https://doi.org/10.1242/jeb.048884

Cribb, A.E., Leeder, J.S., Spielberg, S.P. (1989). Use of a microplate reader in an assay of glutathione reductase using 5,5-dithiobis (2-nitrobenzoic acid). Analytical Biochemistry, 183 , 195-6. https://doi.org/10.1016/0003-2697(89)90188-7

De Lima, D., Roque, G.M., De Almeida, E.A. (2013). In vitro and in vivo inhibition of acetylcholinesterase and carboxylesterase by metals in zebrafish (Danio rerio). Marine Environmental Research, 91, 45-51. https://doi.org/10.1016/j.marenvres.2012.11.005

De, A., Bose, R., Kumar, A., Mozumdar, S. (2014). Targeted delivery of pesticides using biodegradable polymeric nanoparticles. Springer India, New Delhi, pp 59-81.

Denton, D.L., Wheelock, C.E., Murray, S.A., Deanovic, L.A., Hammock, B.D., Hinton, D.E. (2003). Joint acute toxicity of esfenvalerate and diazinon to larval fathead minnows (Pimephales promelas). Environmental Toxicology and Chemistry: An International Journal,22(2), 336-341. https://doi.org/10.1002/etc.5620220214

Di Giulio, R.T., Meyer, J.N. (2008). Reactive oxygen species and oxidative stress. In: Di Giulio, R.T., Hinton, D.E. (Eds.), The Toxicology of Fishes, CRC Press, Boca Raton, FL, pp. 273-324.

Dickinson, D.A., Forman, H.J. (2002). Cellular glutathione and thiols metabolism. Biochemical Pharmacology, 64, 1019-26. https://doi.org/10.1016/S0006-2952(02)01172-3

Djordjevic, J., Djordjevic, A., Adzic, M., Niciforovic, A., Radojcic, M.B. (2010). Chronic stress differentially affects antioxidant enzymes and modifies the acute stress response in liver of Wistar rats. Physiological Research, 59(5), 729-36.

EFSA. (2008). European Food Safety Authority, Conclusion regarding the peer review of the pesticide risk assessment of the active substance penconazole. EFSA Scientific Report, 175, 1-104. https://doi.org/10.2903/j.efsa.2008.119r.

Elia, A.C., Galarini, R., Taticchi, M.I., Dörr, A.J.M., Mantilacci, L. (2003). Antioxidant responses and bioaccumulation in Ictalurus melas under mercury exposure. Ecotoxicology and Environmental Safety, 55,162-7. https://doi.org/10.1016/S0147-6513(02) 00123-9

Erel, O. (2005). A new automated colorimetric method for measuring total oxidant status. Clinical Biochemistry, 38 , 1103-11. https://doi.org/10.1016/j.clinbiochem.2005.08.008 
García-Valcárcel, A.I., Tadeo, J.L. (2012). Influence of moisture on the availability and persistence of clotrimazole and fluconazole in sludge-amended soil. Environmental Toxicology and Chemistry, 31, 501-7. https://doi.org/10.1002/etc.1711

Habig, W.H., Pabst, M.J., Jakoby, W.B. (1974). Glutathione S-transferases, the first enzymatic step in mercapturic acid formation. Journal of Biological Chemistry, 249, 7130-39. https://doi.org/10.1016/ S0021-9258(19)42083-8

Hamed, M., Soliman, H.A.M., Osman, A.G.M., Sayed, A.E.H. (2020). Antioxidants and molecular damage in Nile Tilapia (Oreochromis niloticus) after exposure to microplastics. Environmental Science and Pollution Research, 27, 14581-8. https://doi.org/ 10.1007/s11356-020-07898-y

Hemalatha, D., Amala, A., Rangasamy, B., Nataraj, B., Ramesh, M. (2015). Sublethal toxicity of quinalphos on oxidative stress and antioxidant responses in a freshwater fish Cyprinus carpio. Environmental Toxicology, 31,1399-406 https://doi.org/10.1002/tox.22145

Hongyi, N., Wenjing, D., Qunhe, W., Xingeng, C. (2009). Potential toxic risk of heavy metals from sediment of the Pearl River in South China. Journal of Environmental Sciences, 21, 1053-58. https://doi.org/10.1016/s1001-0742(08)62381-5

IUCN. (2021, October 24). Unio mancus. The IUCN Red List of Threatened Species 2014: e.T22737A42466471. (Lopes-Lima, M., Seddon, M.B. (2014)). https://dx.doi.org/10.2305/IUCN.UK. 2014-3.RLTS.T22737A42466471.en.

IUPAC (2021, October 5) Tebuconazole (Ref: HWG 1608), Environmental fate-ecotoxicology-human health-A to $\mathrm{Z}$ index. Retrieved from https://sitem.herts.ac.uk/aeru/iupac/Reports/610.htm.

Janna, H., Scrimshaw, M.D., Williams, R.J., Churchley, J., Sumpter, J.P. (2011). From Dishwasher to Tap? Xenobiotic Substances Benzotriazole and Tolyltriazole in the Environment. Environmental Science and Technology, 45(9), 385864. https://doi.org/10.1021/es103267g

Jiang, J., Chen, L., Liu, X., Wang, L., Wu, S., \& Zhao, X. (2021). Histology and multi-omic profiling reveal the mixture toxicity of tebuconazole and difenoconazole in adult zebrafish. Science of The Total Environment, 795, 148777.

Jiang, J., Shi, Y., Yu, R., Chen, L., Zhao, X. (2018). Biological response of zebrafish after short-term exposure to azoxystrobin. Chemosphere, 202, 56-64. https://doi.org/10.1016/j.chemosphere.2018.03.055

Korkmaz, V., Güngördü, A., Ozmen, M. (2018). Comparative evaluation of toxicological effects and recovery patterns in zebrafish (Danio rerio) after exposure to phosalone-based and cypermethrin-based pesticides. Ecotoxicology and Environmental Safety, 160, 265-72. https://doi.org/10.1016/j.ecoenv. 2018.05.055
Lenfant, N., Hotelier, T., Velluet, E., Bourne, Y., Marchot, P., Chatonnet, A. (2012). ESTHER, the database of the $\alpha / \beta$-hydrolase fold superfamily of proteins: tools to explore diversity of functions. Nucleic Acids Research,41, 423-29. https://doi.org/10.1093/nar/gks1154

Liu, N., Dong, F., Xu, J., Liu, X., Zheng, Y. (2016). Chiral bioaccumulation behavior of tebuconazole in the zebrafish (Danio rerio). Ecotoxicology and Environmental Safety, 126, 78-84. https://doi.org/10.1016/j.ecoenv.2015.12.007

Ma, F., Li, Y., Yu, Y., Li, Z., Lin, L., Chen, Q., Xu, Q., Pan, P., Wang, Y., Ge, R.S. (2021). Gestational exposure to tebuconazole affects the development of rat fetal leydig cells. Chemosphere, 262, 127792. https://doi.org/10.1016/j.chemosphere.2020.127792

Mahfouz, R., Sharma, R., Sharma, D., Sabanegh, E., Agarwal, A. (2009). Diagnostic value of the total antioxidant capacity (TAC) in human seminal plasma. Fertility and Sterility, 91, 805-11. https://doi.org/10.1016/j.fertnstert.2008.01.022

McNeill, K.S., Cancilla, D.A. (2009). Detection of triazole deicing additives in soil samples from airports with low, mid, and large volume aircraft deicing activities. Bulletin of Environmental Contamination and Toxicology, 265-9. https://doi.org/10.1007/s00128-008-9626-z

Mercan, U. (2004). Toksikolojide serbest radikallerin önemi. Yüzüncü Yıl Üniversitesi Veteriner Fakültesi Dergisi, 15(1), 91-6.

Moreira, S.M., Moreira-Santos, M., Rendón-von Osten, J., Da Silva, E.M., Ribeiro, R., Guilhermino, L., Soares, A.M.V.M. (2010). Ecotoxicological tools for the tropics: Sublethal assays with fish to evaluate edge-of-field pesticide runoff toxicity. Ecotoxicology and Environmental Safety, 73(5), 893-9. https://doi.org/10.1016/j.ecoenv. 2010.04.007

Moreno, I., Pichardo, S., Jos, A., Gomez-Amores, L., Mate, A., Vazquez, C. M., Camean, A. M. (2005). Antioxidant enzyme activity and lipid peroxidation in liver and kidney of rats exposed to microcystin-LR administered intraperitoneally. Toxicon, 45(4), 395402. https://doi.org/10.1016/j.toxicon.2004.11.001

Moron, M.S., Depierre, J.W., Mannervik, B. (1979). Levels of glutathione, glutathione reductase and glutathione S-transferase activities in rat lung and liver. Biochimica et Biophysica Acta (BBA)-General Subjects, 582(1), 67-78. https://doi.org/10.1016/03044165(79)90289-7

Naimo. T.J. (1995). A review of the effects of heavy metals on freshwater mussels. Ecotoxicology, 4, 34162. https://doi.org/10.1007/BF00118870

Narra, M.R., Rajender, K., Reddy, R.R., Rao, J.V., Begum, G. (2015). The role of vitamin $\mathrm{C}$ as antioxidant in protection biochemical and haematological stress induced by chlorpyrifos in freshwater fish Clarias batrachus. Chemosphere, 132, 172-8. $\quad$ https://doi.org/10.1016/j.chemosphere.2015. $\underline{03.006}$ 
Nikolaou, S., Efstathiou, P., Tiggiridou, M., Arabatzis, N., Piera, Y., Aletrari, M. (2017). Monitoring of pesticides in drinking, surface and ground water of Cyprus by liquid-liquid and solid phase extraction in combination with GC/MS and UPLC/MS/MS. Journal of Water Resource and Protection, 9, 1184-98. https://doi.org/10.4236/jwarp.2017.910077

Nong, Q.Y., Liu, Y.A., Qin, L.T., Liu, M., Mo, L.Y., Liang, Y.P., Zeng, H.H. (2021). Toxic mechanism of three azole fungicides and their mixture to green alga Chlorella pyrenoidosa. Chemosphere, 262, 127793. https://doi.org/10.1016/j.chemosphere.2020.127793

Oruç, E.Ö. (2010). Oxidative stress, steroid hormone concentrations and acetylcholinesterase activity in Oreochromis niloticus exposed to chlorpyrifos. Pesticide Biochemistry and Physiology, 96(3), 160-6. https://doi.org/10.1016/j.pestbp.2009.11.005

Pacholak, A., Burlaga, N., Frankowski, R., ZgołaGrześkowiak, A., Kaczorek, E. (2022). Azole fungicides:(Bio) degradation, transformation products and toxicity elucidation. Science of the Total Environment, 802, 149917. https://doi.org/10.1016/j.scitotenv.2021.149917

Parke, D.V., Piotrowski, J.K. (1996). Glutathione: its role in detoxication of reactive oxygen species and environmental chemicals. Toxicology, 4(1), 1-13.

Peng, X., Huang, Q., Zhang, K., Yu, Y.,Wang, Z.,Wang, C. (2012). Distribution, behavior and fate of azole antifungals during mechanical, biological, and chemical treatments in sewage treatment plants in China. Science of the Total Environment, 426, 311-17. https://doi.org/10.1016/j.scitotenv.2012.03.067

Perendija, B.R., Borkovic, S.S., Kovacevic, T.B., Pavlović, S.Z., Stojanović, B.D., Paunovic, M.M., Cakic, P.D., Radojicic, R.M., Pajović, S.B., Saičić, Z.S. (2007). Glutathione dependent enzyme activities in the foot of three freshwater mussel species in the Sava River, Serbia. Archives of biological sciences, 59(3), 169-75. http://dx.doi.org/10.2298/ ABS0703169P

Pinchuk, I., Shoval, H., Dotan, Y., Lichtenberg, D. (2012). Evaluation of antioxidants: scope, limitations and relevance of assays. Chemistry and Physics of Lipids, 165, 638-47. https://doi.org/10.1016/j. chemphyslip.2012.05.003

Placer, Z.A., Cushman, L.L., Johnson, B.C. (1966). Estimation of product of lipid peroxidation (malonyl dialdehyde) in biochemical systems. Analytical Biochemistry, 16(2), 359-64. https://doi.org/10.1016/0003-2697(66)90167-9

PPDB. (2021, October 24). Pesticide Properties DataBase. University of Hertford-shire. Retrieved from http://sitem.herts.ac.uk/aeru/ppdb/en/Reports 1509.htm

Regoli, F. (2000). Total Oxyradical Scavenging Capacity (TOSC) in Polluted and Translocated Mussels: A Predictive Biomarker of Oxidative Stress. Aquatic Toxicology, 50, 351-61. https://doi.org/10.1016/ S0166-445X(00)00091-6

Ross, M.K., Streit, T.M., Herring, K.L., Xie, S. (2010). Carboxylesterases: dual roles in lipid and pesticide metabolism. Journal of Pesticide Science, 35, 257-64. https://doi.org/10.1584/jpestics.R10-07
Santhoshkumar, P., Shivanandappa, T. (1999). In vitro sequestration of two organophosphorus homologs by the rat liver. Chemico-Biological Interactions, 119, 277-82. $\quad$ https://doi.org/10.1016/s0009-2797(99) $\underline{00037-X}$

Sayed, A.E.H., Abu Khalil, N.S. (2016). Oxidative Stress Induction in Monosex Nile Tilapia (Oreochromis niloticus, Linnaeus, 1758): A Field Study on the Side Effects of Methyltestosterone. Journal of Aquaculture Research and Development, 7, 1-6. https://doi.org/10.4172/2155-9546.1000416

Sayeed, I., Parvez, S., Pandey, S., Bin-Hafeez, B., Haque, R., \& Raisuddin, S. (2003). Oxidative stress biomarkers of exposure to deltamethrin in freshwater fish, Channa punctatus Bloch. Ecotoxicology and Environmental Safety, 56(2), 295-301. https://doi.org /10.1016/S0147-6513(03)00009-5

Schafer, F.Q., Buettner, G.R. (2001). Redox environment ofthe cell as viewed through glutathione disulfide/glutathione couple. Free Radical Biology and Medicine, 30, 1191-212. https://doi.org/ 10.1016/S0891-5849(01)00480-4

Sehonova, P., Plhalova, L., Blahova, J., Doubkova, V., Prokes, M., Tichy, F., Fiorino, E., Faggio, C., Svobodova, Z. (2017). Toxicity of naproxen sodium and its mixture with tramadol hydrochloride on fish early life stages. Chemosphere, 188, 414-23. https://doi.org/10.1016/j.chemosphere.2017.08.151

Sun, Y., Oberley, L.W., Li, Y. (1988). A simple method for clinical assay of superoxide dismutase. Clinical Chemistry, 34, 497-500. https://doi.org/10.1093/ clinchem/34.3.497

U.S.EPA (2020). Aquatic life benchmarks and ecological risk assessments for registered pesticides. Retrieved April 7, 2021, from https://www.epa.gov/pesticidescience-andassessing-pesticide-risks/aquatic-lifebenchmarks-and-ecological-risk.

Uçkun, A.A., Öz, Ö.B. (2020). Acute exposure to the fungicide penconazole affects some biochemical parameters in the crayfish (Astacus leptodactylus Eschscholtz, 1823). Environmental Science and Pollution Research,27(28), 35626-37. https://doi.org/10.1007/s11356-020-09595-2

Uçkun, A.A., Öz, Ö.B. (2021). Evaluation of the acute toxic effect of azoxystrobin on non-target crayfish (Astacus leptodactylus Eschscholtz, 1823) by using oxidative stress enzymes, ATPases and cholinesterase as biomarkers. Drug and Chemical Toxicology, 44(5), 550-7. https://doi.org/10.1080/01480545.2020.1774 $\underline{604}$

Uçkun, A.A., Uçkun, M. (2021). Evaluation of Some Biomarkers in Carp (Cyprinus carpio Linnaeus, 1758) Depending on Water and Sediment Pollution of Atatürk Dam Lake. Bitlis Eren Üniversitesi Fen Bilimleri Dergisi, 10(3), 744-53. https://doi.org/10.17798/bitlisfen.898021

Uçkun, M., Alkan Uçkun, A. (2021). Tatlı Su Midyelerine (Unio mancus) İmidakloprid Uygulanmasının Solungaç ATPaz Aktiviteleri Üzerine Etkisi. Erciyes Üniversitesi Fen Bilimleri Enstitüsü Fen Bilimleri Dergisi, 37(1), 91-98. 
Uçkun, M., Özmen, M. (2021). Evaluating Multiple Biochemical Markers in Xenopus laevis Tadpoles Exposed to the Pesticides Thiacloprid and Trifloxystrobin in Single and Mixed Forms. Environmental Toxicology and Chemistry, 40(10), 2846-60. https://doi.org/10.1002/etc.5158

Uçkun, M., Yoloğlu, E., Uçkun, A.A., Öz, Ö.B. (2021). Acute Toxicity of Insecticide Thiamethoxam to Crayfish (Astacus leptodactylus): Alterations in Oxidative Stress Markers, ATPases and Cholinesterase. Acta Chimica Slovenica, 68(3), 52131. http://dx.doi.org/10.17344/acsi.2021.6823

Vahdati Hassani, F., Abnous, K., Mehri, S., Jafarian, A., Birner-Gruenberger, R., Yazdian Robati, R., Hosseinzadeh, H. (2018). Proteomics and phosphoproteomics analysis of liver in male rats exposed to bisphenol A: Mechanism of hepatotoxicity and biomarker discovery. Food and Chemical Toxicology, $\quad 112, \quad 26 \quad-38$. https://doi.org/10.1016/j.fct.2017.12.021

Van Rensburg, S.J., Carstens, M.E., Potocnik, F.C.V., Van Der Spuy, G., Van Der Walt, B.J., Taljaard, J.J.F. (1995). Transferrin C2 and Alzheimer's disease: another piece of the puzzle found? Medical Hypotheses, 44(4), 268-72. https://doi.org/10.1016/ 0306-9877(95)90178-7

Wheelock, C.E., Eder, K.J., Werner, I., Huang, H., Jones, P.D., Brammell, B.F., Elskus, A.A., Hammock, B.D. (2005). Individual variability in esterase activity and CYP1A levels in Chinook salmon (Oncorhynchus tshawytscha) exposed to esfenvalerate and chlorpyrifos. Aquatic Toxicology, 74(2), 172-92. https://doi.org/10.1016/j.aquatox.2005.05.009

Winston, G.W., Di Giulio, R.T. (1991). Prooxidant and antioxidant mechanisms in aquatic organisms. Aquatic toxicology, 19(2), 137-61. https://doi.org/10.1016/0166-445X(91)90033-6

Yonar, S.M., Ural, M.Ş., Silici, S., Yonar, M.E. (2014). Malathion-induced changes in the haematological profile, the immune response, and the oxidative/antioxidant status of Cyprinus carpio carpio: Protective role of propolis. Ecotoxicology and Environmental Safety, 102, 202-9. https://doi.org/10.1016/j.ecoenv.2014.01.007

Yoloğlu, E. (2019). Assessment of $\mathrm{Na}^{+} / \mathrm{K}^{+}$-ATPase, $\mathrm{Mg}^{2+}$ ATPase, $\mathrm{Ca}^{2+}$-ATPase, and Total-ATPase Activities in Gills of Freshwater Mussels Exposed to Penconazole. Commagene Journal of Biology, 3(2), 88-92. https://doi.org/10.31594/commagene.632082 